\title{
CONTINUATION OF THE PALAEOMAGNETIC FIELD WORK IN EASTERN NORTH GREENLAND
}

\section{Christian Marcussen}

The aim of the 1980 field work was to extend the collection of orientated rock samples from North Greenland obtained in 1979 (Abrahamsen \& Marcussen, 1980). The material consists of Upper Proterozoic to Lower Palaeozoic sediments as well as the presumed interglacial sediments at Kap København (Table 5).

The two years' palaeomagnetic field work has resulted in a nearly complete collection of orientated rock samples from all formations older than the Silurian flysch. The collection may be divided into six stratigraphical units (figs 28,29 ).

1. The Proterozoic Independence Fjord Group. The palaeomagnetic data may reveal the relationship between the Inuiteq Sø and the Norsemandal Formations.

2. The Proterozoic Zig-Zag Dal Basalt Formation and the Midsommersø dolerites.

3. The Eocambrian(?) Campanuladal, Morænesø and Fyns Sø Formations. The palaeomagnetic data may help in the investigation of the age relationships between these formations and yield relevant palaeomagnetic pole positions.

4. The Early Cambrian Portfjeld Formation. Samples from the lower part of this formations have yielded microfossils, which indicate an Early Cambrian age (Peel, 1980). Palaeomagnetic data may further produce a magneto-stratigraphy for this formation and thus for the Early Cambrian of North Greenland. Also global correlations may be possible from this study.

5. The Cambrian-Silurian platform sequence of mostly carbonate rocks. This sequence may yield palaeomagnetic pole positions.

Table 5. Summary of palaeomagnetic samples, eastern North Greenland, 1980

\begin{tabular}{|c|c|c|c|c|c|c|}
\hline Formation/rock type & Locality & $\begin{array}{l}\text { No of } \\
\text { sites }\end{array}$ & $\begin{array}{c}\text { No of } \\
\text { profiles }\end{array}$ & $\begin{array}{l}\text { No of } \\
\text { hand- } \\
\text { samples }\end{array}$ & $\begin{array}{l}\text { orientat } \\
\text { drilled } \\
\text { cores }\end{array}$ & ted \\
\hline $\begin{array}{l}\text { Sedimentary sequence } \\
\text { (presumed interglacial) }\end{array}$ & Kap København & 2 & 6 & & $275^{+}$ & 275 \\
\hline Silur. lst., mb.A & North of Domkirken & & 1 & 4 & 7 & 11 \\
\hline Silur. dolom., up mb. & North of Domkirken & & 1 & 8 & 1 & 9 \\
\hline Berglum Rv. Fm., lr mb. & North of Domkirken & & 1 & & 68 & 68 \\
\hline Wandel Val. Fm., mid mb. & South of Domkirken & & 1 & & 98 & 98 \\
\hline Bronl'd Fj gr, mb.A,B,C & Pyramideplateau & & 3 & 31 & & 31 \\
\hline Buen $\mathrm{Fm}$. & Fastelavnssø & 1 & 1 & 4 & 46 & 50 \\
\hline Fyns Se Fm. & J.C.Christensen Ld & & 2 & 31 & & 31 \\
\hline Campanuladal Fm. & J.C.Christensen Ld & & 6 & 77 & & 77 \\
\hline Midsommersø dolerite* & Heilprin Land & 3 & & & 35 & 35 \\
\hline Total & & 6 & 22 & 155 & 530 & 685 \\
\hline
\end{tabular}




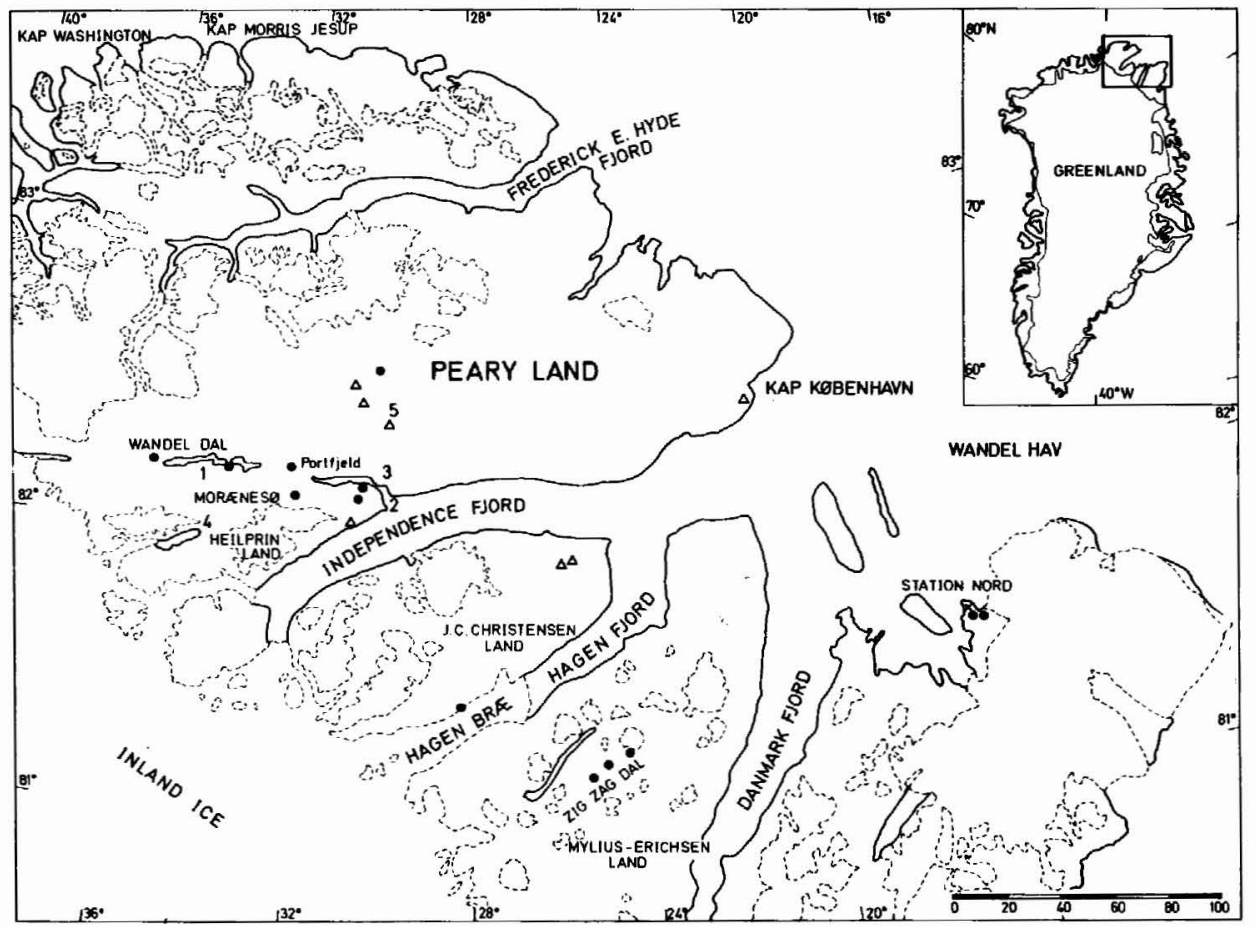

Fig. 28. Map of Peary Land, eastern North Greenland. Broken lines indicate ice covered areas. Palaeomagnetic sampling areas are shown by dots for 1979 and by open triangles for 1980 (cf. Table 5). Localities: 1: Øvre and Nedre Midsommersø, 2: Jørgen Brønlund Fjord, 3: Fastelavnssø, 4: Ítukussuk Dal, 5: Domkirken.

6. The presumed interglacial sedimentary sequence at Kap København and the postglacial sediments from the Brønlund Fjord region. This material will be used in investigations of the Quaternary magneto-stratigraphy and geomagnetic secular variation in Greenland (Abrahamsen, 1980).

\section{Preliminary palaeomagnetic results from the Proterozoic Zig-Zag Dal Basalt Formation and the Midsommersø dolerites}

Rock magnetic results and natural remanent magnetisation directions from the Zig-Zag Dal Basalt Formation and the Midsommersø dolerites have been presented previously (Abrahamsen \& Marcussen, 1980). Magnetic cleaning using partial alternating field demagnetization has been carried out on all samples from the basalt and dolerite sites. Seventeen sites in the basalt and ten sites in the dolerites appear to have primary components of stable magnetization with precise grouping of directions at each site. The mean palaeomagnetic pole positions for the two rock types are not significantly different (Table 6). If Davis Strait is closed according to Bullard et al. (1965) then the two Greenland poles compare closely to the North American Apparent Polar Wander (APW) path, for the time interval 1100-1500 
STRATIGRAPHICAL UNIT

Main lithology

\begin{tabular}{|c|c|c|}
\hline$\underset{\frac{1}{\alpha}}{\frac{\alpha}{b}}$ & $\begin{array}{l}\text { clay silt } \\
\text { sand } \\
\text { gyttja }\end{array}$ & $\begin{array}{l}\text { Postglacial, marine sed. } \\
\text { Postglacial, limnic (lake sed.) }\end{array}$ \\
\hline 引 & $\begin{array}{l}\text { clay silt } \\
\text { sand }\end{array}$ & $\begin{array}{l}\text { Presumed interglacial sed. } \\
\text { at Kap København }\end{array}$ \\
\hline
\end{tabular}

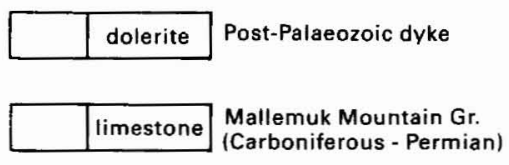

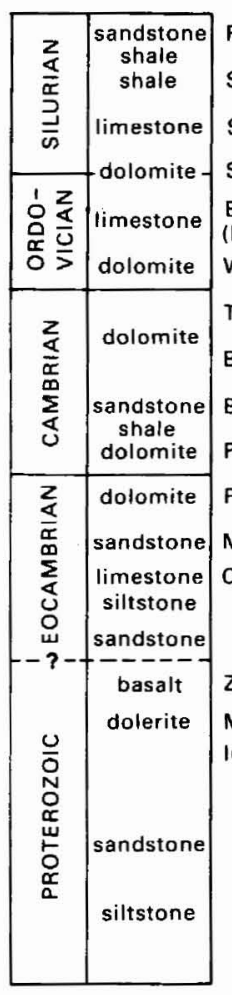

Flysch units

Silurian shale $\mathrm{fm}$.

Silurian limestone $\mathrm{fm} ., \mathrm{mb} . \mathrm{A}$

Silurian dolomite $\mathrm{fm}$., upper $\mathrm{mb}$.

Børglum River Fm.

(lower mb., unit 7-9)

Wandel Valley $\mathrm{Fm}$., middle mb.

Tavsens Iskappe Gr.

Brønlund Fiord Gr.

Buen Fm.

Portfjeld Fm.

Fyns Sø Fm.

Morænes $\varnothing \mathrm{Fm}$.

Campanuladal Fm.

Multicoloured mb.

Basal sandstone $\mathrm{mb}$.

Zig-Zag Dal Basalt Fm.

Midsommers $\emptyset$ dolerite ( 1250 m.y.)

Independence Fjord $\mathrm{Gr}$.

Fiil Fjord Mb.

Kap Stadil Mb.

Hagen Bræ Mb.

Himmerlanddal Mb.

Baggården Mb.

No. of samples
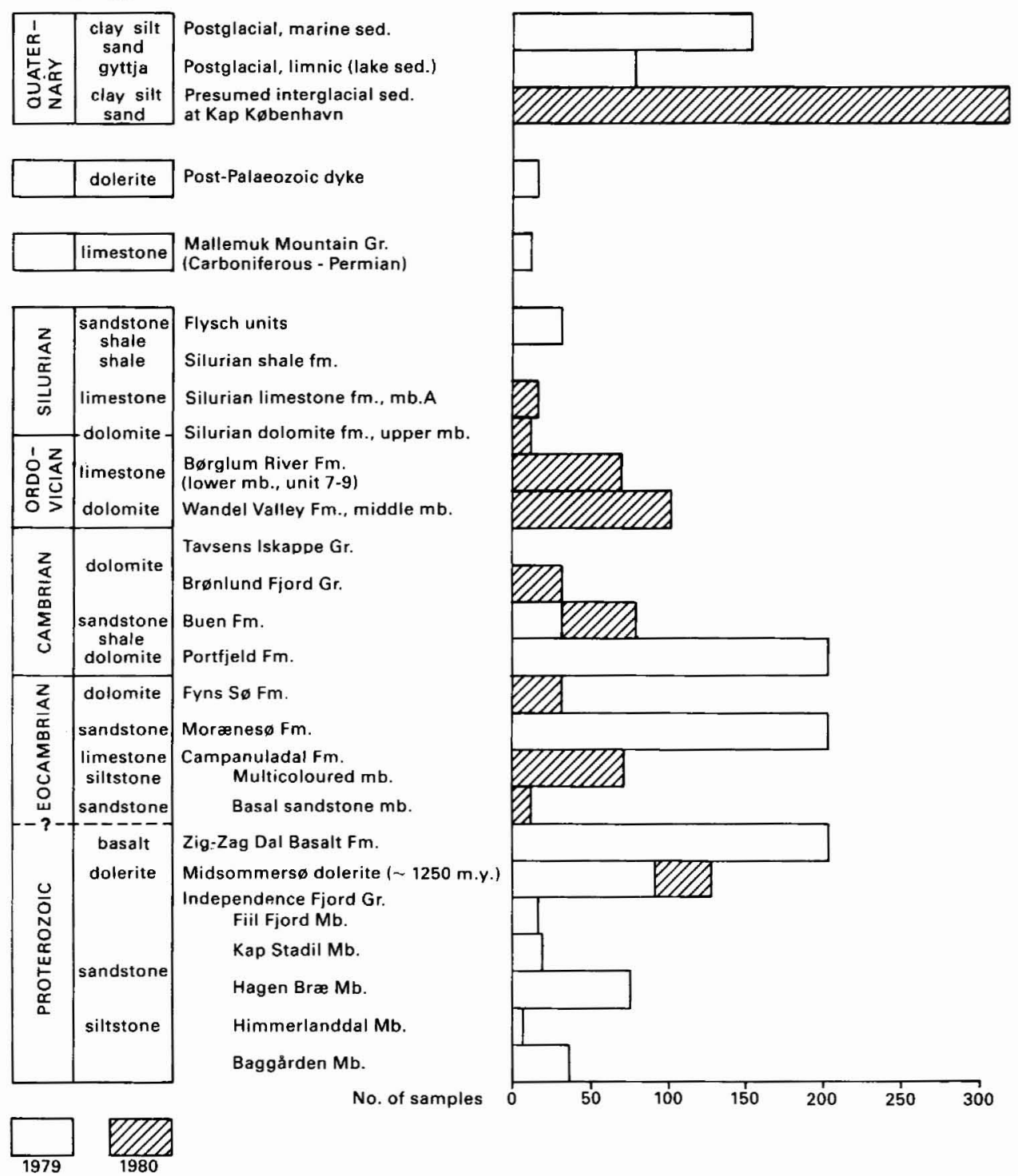

Fig. 29. Stratigraphical distribution of palaeomagnetic samples from eastern North Greenland.

m.y. (cf. Berger \& York, 1980). This suggests a palaeomagnetic age for the basalt and the dolerites of about $1300 \mathrm{~m} . \mathrm{y}$. (fig. 30) and this age is in close agreement with Rb-Sr whole-rock isochron ages of $c .1250 \mathrm{~m}$.y. obtained on granophyric intrusives, which are thought to be genetically related to the overlying basalt (Jepsen \& Kalsbeek, 1979).

Acknowledgement. The field work was carried out with Ole Bennike, whose help is appreciated. 
Table 6. Mean palaeomagnetic pole positions after cleaning

\begin{tabular}{|c|c|c|c|c|c|c|c|c|}
\hline Rock type & $\begin{array}{l}\text { No of } \\
\text { sites }\end{array}$ & $\begin{array}{c}\text { No of } \\
\text { samples }\end{array}$ & $\begin{array}{c}\text { Pole } \\
\text { before } \\
\text { Lat. }\end{array}$ & $\begin{array}{l}\text { position } \\
\text { rotation } \\
\text { Long. }\end{array}$ & $\begin{array}{l}\text { Pole po } \\
\text { after r } \\
\text { Lat. }\end{array}$ & $\begin{array}{l}\text { osition } \\
\text { rotation } \\
\text { Long. }\end{array}$ & K & ${ }^{A} 95$ \\
\hline Basalt & $17(24)$ & 127 & $12.3^{\circ} 5$ & $63.7^{\circ} \mathrm{E}$ & $15.2^{\circ} \mathrm{s}$ & $48.7^{\circ} \mathrm{E}$ & 100.6 & 3.6 \\
\hline Dolerites & $10(12)$ & 94 & $8.3^{\circ} \mathrm{S}$ & $63.0^{\circ} \mathrm{E}$ & $11.3^{\circ} \mathrm{S}$ & $46.9^{\circ} \mathrm{E}$ & 95.4 & 5.0 \\
\hline
\end{tabular}

Note: Mean pole positions calculated from site pole positions.

No. of acceptable collecting sites with total number of sites

sampled in parenthesis.

$K$ and $A$ : precision parameter and radius of $95 \%$ confidence circle

about the mean pole (Fischer, 1953; McElhinny, 1973).

\section{References}

Abrahamsen, N. 1980: Magnetic secular variation in postglacial marine sediments of Brønlund Fjord, Peary Land, eastern North Greenland. Rapp. Grønlands geol. Unders. 99, 147-152.

Abrahamsen, N. \& Marcussen, C. 1980: Preliminary results of rock- and palaeomagnetic field work in Peary Land; North Greenland. Rapp. Grønlands geol. Unders. 99, 137-145.

Berger, G. W. \& York, D. 1980: Reinterpretation of the North American apparent polar wander curve for the interval 800-1500 Ma. Can. J. Earth Sci. 17, 1229-1235.

Bullard, E. C., Everett, J. E. \& Smith, A. G. 1965: The fit of the continents around the Atlantic. Phil.

Trans. R. Soc. Lond. A 258, 41-51.

Fischer, R. 1953: Dispersion on a sphere. Proc. R. Soc. Lond. A 217, 295-305.

Jepsen, H. \& Kalsbeek, F. 1979: Igneous rocks in the Proterozoic platform of eastern North Greenland.

Rapp. Grønlands geol. Unders. 88, 11-14.

McElhinny, M. W. 1973: Palaeomagnetism and plate tectonics. 357 pp. Cambridge: University Press.

Peel, J. S. 1980: Early Cambrian microfossils from the Portfjeld Formation, Peary Land, eastern North

Greenland. Rapp. Grønlands geol. Unders. 100, 15-18.

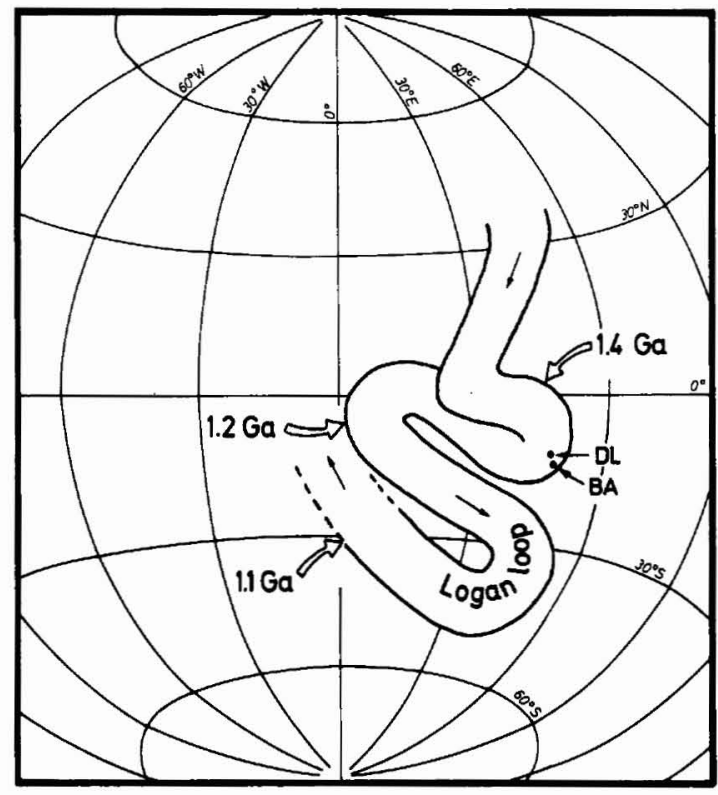

Fig. 30. A North American Apparent Polar Wander path for the time interval 1.1.-1.5. Ga (adapted from Berger \& York, 1980). The curve has a width of $15^{\circ}$ and is based on 36 reliable palaeopoles for the time interval. For further details see Berger \& York (1980). BA: mean pole position for the Zig-Zag Dal Basalt Formation (cf. Table 6). DL: mean pole position for the Midsommersø dolerites (cf. Table 6). Both pole positions have been corrected for Phanerozoic drift of Greenland according to the Bullard et al. (1965) continental reconstruction. 